\title{
A Review of Social Career Cognitive Theory (SCCT) For Career Decision Self-Efficacy (CDSE)
}

\author{
Nik Rafidah binti Nik Yusoff, Mastura binti Mahfar, Muhammad Sukri bin Saud
}

\begin{abstract}
Career self-efficacy is an important aspect of making choice, planning, and decision-related to career. Social Career Cognitive Theory (SCCT) is a career theory explaining the career self-efficacy aspect. SCCT has been expanded in the career aspect in 1994 which emphasis interest, career choice and performance aspect. Besides that, SCCT also emphasizes the importance of self-efficacy in career development externally and internally. This article elaborates on SCCT and the importance of SCCT in explaining the career self-efficacy (CSE) aspect. There are a few theories related to individual career aspects, namely Life Span Theory (Super, 1957), Holland's Theory (Holland, 1959) and Social Cognitive Career Theory (SCCT). However, SCCT has been chosen as a theoretical base to explain the CSE based on the justifications addressed in this article.
\end{abstract}

Keywords: Social Cognitive Career Theory (SCCT), Career Self-Efficacy, Life Span Theory, Holland's Theory.

\section{INTRODUCTION}

S+ Social Cognitive Career Theory (SCCT) was originally introduced by Bandura in 1986 with the name Social Cognitive Theory (Patton, 1999; Lent et al. 1996). In 1970, Albert Bandura introduced SCCT with the name Social Learning Theory (Brown, Brooks and Associates, 1996). Later, in 1977, Bandura introduced self-efficacy that focused on the Behavioral Change Theory which was identified as an important aspect to increase confidence, ability, and trust to self. (Brown et al. 1996).

Beginning in 1980, the Social Cognitive Theory focuses on the self-efficacy development, namely strength, confidence and individual trust that will affect the excellence in his career and life (Scharf, 2006). Social Cognitive Career Theory was also revised and a few changes were made from the Social Cognitive Theory (Bandura, 1986; 1997; 2000; 2003; 2006; 2007). For example, Social Career Cognitive Theory added that experience while learning, genetic factors, and environment also affect career decision making (Patton, 1999).

Hence, Social Career Cognitive Theory was improvised and expanded in the career aspect starting in 1994 by Lent et al. to emphasize the interest, career choice and performance aspects (Lent et al. 1994; 1996). Social Career Cognitive Theory also emphasizes the importance of self-efficacy in the development of a career internally and externally

Revised Manuscript Received on April 19, 2019.

Nik Rafidah binti Nik Yusoff*, Azman Hashim International Business

Mastura binti Mahfar, Faculty of Social Sciences and Humanities, UTM, Malasiya. (Email: mastura@management.utm.my)

Muhammad Sukri bin Saud, Faculty of Social Sciences and Humanities, UTM, Malasiya.(Email: p-sukri@utm.my) School, UTM, Malasiya. (Email: nikrafidah@utm.my)

(Gushue, 2006; Lent et al. 1994; 1996; Nauta, 2004). Social Career Cognitive Theory focuses on three things, namely the development and explanation interest regarding career, academic and career choice, and performance and hard work in education and career (Lent et al. 1994). Meanwhile for career self-efficacy (CSE) refers to an individual's confidence and believe of himself towards career choice, effective career decision making and to make the desired choice (Hackett and Betz, 1981). Whereas Betz and Hackett (1986) stated that career self-efficacy is an expectation towards self-efficacy related to behaviors needed in career choice and career adjustment.

Furthermore, career self-efficacy also refers to an individual's ability to make consideration, organize and accomplish the desired action to achieve the goal according to skills (Zalizan et al. 2013). According to Mohd Izwan Mahmud et al. (2016), career self-efficacy is an element that can measure career readiness in the career development process and can be increased with a systematic method.

Besides that, career self-efficacy also closely related to individual perception towards self ability that will help control the anxiety in a particular environment (Chiesa et al. 2016). Studies that relate to career self-efficacy include selfefficacy in career decision (Gianakos, 2001), exploration and career plan (Rogers, Creed, and Glendon, 2008), and career choice (Jin, Watkins, and Yuen, 2009; Wang, Jome, Haase and Bruch, 2006). Further, career self-efficacy can also help decrease the problems related to career decisions (Fouad, Cotter, and Kantamneni, 2009). A study on students at Midwestern university found that students' career selfefficacy increase after joining the career intervention (Fouad et al. 2009). Thus, if the students enroll in the career planning course, it is easier for them to make the career choice, be confident towards the career decision and increase their career development, compared to the students who do not enroll in the course (Reese and Miller, 2006).

\section{A. Theories Related to Career Self-Efficacy}

A few theories will be featured in this article to discuss the career self-efficacy aspect, namely Life Span Theory (Super, 1957), Holland's Theory (1959) and Social Cognitive Career Theory (Bandura, 1986; Lent et al. 1996). However, SCCT will be the theoretical based to explain CSE. 


\section{B. Life Span Theory}

From the history of the name, Career Development Theory started with 'Career Development Theory' in 1953 and changed to 'Career Development: Self-Concept Theory' in 1963 (Savickas, 1997). Then, the Super theory was changed to 'Career Psychology' in 1971, and later to the latest name, that is Life Span Theory (Savickas, 1997). Super also depends on the Trait and Factor Theory and Super technique conducts counseling sessions with his clients to develop Life Span Theory (Savickas, 1997).
According to Isaacson and Brown (2000), Life Span Theory emphasis on the career development phases, stages and the development of individual career self-concept. Selfconcept refers to how an individual sees himself and the situation resulting from the combination of biology characteristics, individual roles in social and evaluation to the reaction of the individual towards other people (Scharf, 2010; 2006). Based on the concept, Super (1971) divides the self-concept into five phases as follows:

Table 1. Stage, phase and the characteristics for Life Span Theory

\begin{tabular}{cc}
\hline No. & Development Phase \\
\hline 1. & Growth phase (Birth until 14 years)
\end{tabular}

\section{Characteristics}

Self-concept starts to develop during the growth phase through influence by family and school. Individual also develops want and clear fantasy, interest, and skills also have the courage to involve in social activities.

Growth Phase has 3 stages, namely:

i)

Fantasy stage (5 to 10 years)

ii) Interest stage (11 to 12 years)

iii) Ability stage (13 to 14 years)

2.
Exploration Stage (15 to 24 years)

ii)

Transitional phase (18 to 21 years)

iii)

Trial phase (22 to 24 years)

Exploration stage has three phases, namely:

i) Tentative phase (15 to 17 years)
Need and fantasy are playing their role.

Interest becomes important in doing activities and to determine goals for himself. An individual also can identify types of careers, the importance of careers and identify other structures in his society.

An individual will consider between the want and his ability. An individual can also identify the difference between an individual according to the job.

An individual explores a lot about career, including self-evaluation, role play, and career exploration and doing part-time during free time. At this stage, an individual has identified and chosen an accurate career.

An individual is concerned about his need, interest, values and considers the available opportunity. The tentative choice is made when career choices are limited and indefinite.

During this phase, an individual starts to find his selfconcept, moves from choosing the suggested careers to choose a particular career.

An individual identifies the accurate career field, chooses a suitable career, starts to get a job or training, completes the industrial training and starts to work. 


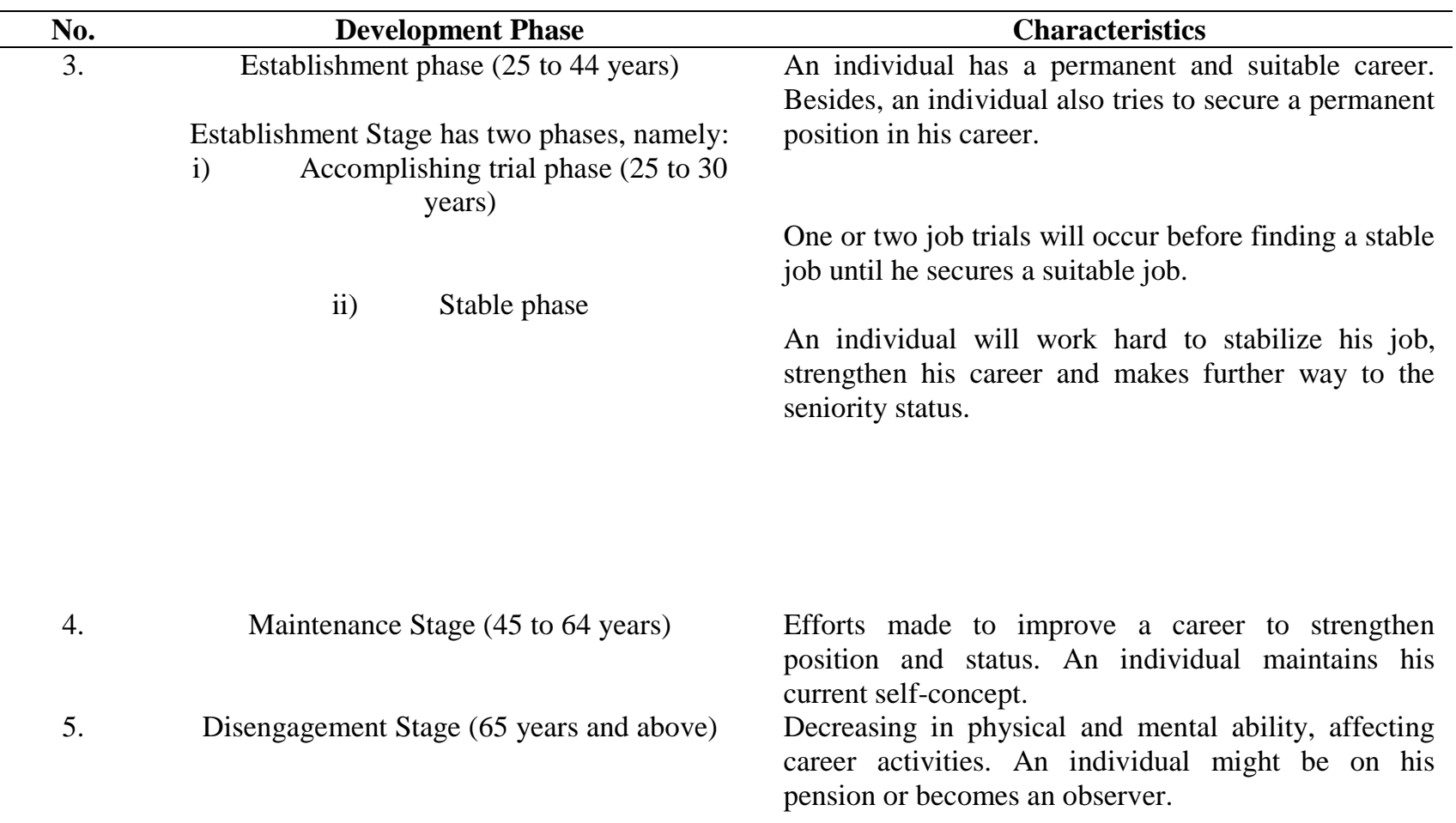

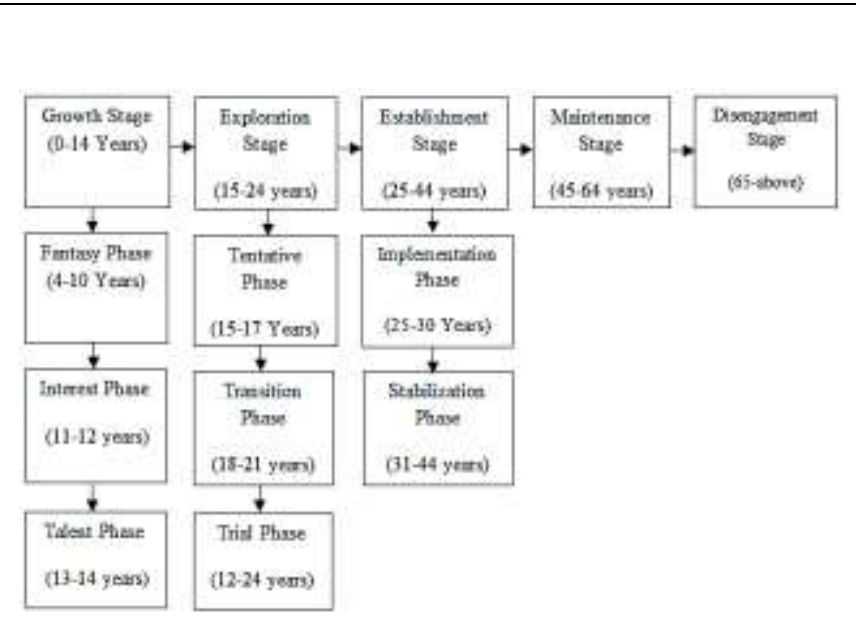

the relationship between personality type with job environment in correlation and coefficiently (Holland, 1978; 1985; 1996) as in Fig. 1.2. Hexagonal Model functions to define the degree of personality pattern consistency, environment pattern and degree of congruency between individual and environment (Holland, 1973; 1985; 1996).

Other than that, the Hexagonal Model is also related to the main ideas so that they can be used in dealing with practical and theoretical problems (Holland, 1985; 1996).

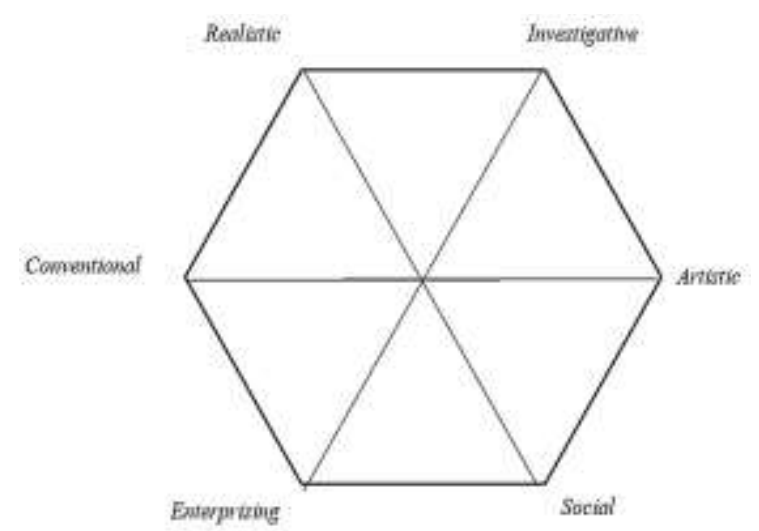

Fig. 1.2. Holland Hexagonal Model (Source from Holland et al. 1969)

Holland's Theory was developed by John L. Holland in 1959 and updated in 1966, 1973, 1978, 1985 and 1996 (Holland et al. 1969). In 1966, Holland identified six main categories in the vocational Preference Inventory (VPI), which are Realist (R), Investigative (I), Artistic (A), Social (S), Enterprising (E), and Conventional (C).

Holland also introduced Hexagonal Model that explained 
International Conference on Recents Advancements in Engineering and Technology (ICRAET-18) |15th and 16th March 2019|Siddhartha Institute of Technology \& Sciences, Telangana, India.

Table 1.2. General characteristics by types of personalities (Source: Holland, 1973 and

\begin{tabular}{|c|c|c|}
\hline No & Personality Type & General Characteristics \\
\hline 1. & Realistic (R) & $\begin{array}{l}\text { Interest in realistic jobs involving } \\
\text { tools, machines, and animals that can } \\
\text { be controlled by the individual. } \\
\text { Has technical skills } \\
\text { Self-perception of having the skills in } \\
\text { mechanical and sports. }\end{array}$ \\
\hline 2. & Investigative (I) & $\begin{array}{l}\text { Finding solutions through interest and } \\
\text { scientific and mathematical } \\
\text { competency } \\
\text { Assuming self as a scholar, an } \\
\text { intellect, and lack of leadership skill } \\
\text { Does not like to use machine and tool } \\
\text { Has high value towards science }\end{array}$ \\
\hline
\end{tabular}

3. $\quad$ Artistic (A)

Interests in work related to art Assuming self as an expressive, genuine, free, creative, imaginative, intuitive, not conform, does not like rules, has artistic talent, music, activities and writing talent Gives high value towards aesthetic quality Personality Characteristics
Anti-social
Confirm
Honest
Genuine
Hard-headed
Materialistic
Natural
Loner

Not flexible

Conscientious

Analytical

Free

Rational

Careful

Introspective

Critical

Quiet

Humble

Curious

Precise

Difficult

Imaginative

Impractical

Disorderly

Emotional

Expressive

Idealistic

Impulsive

Free

Introspective

Intuitive

Influencer

4. $\quad$ Social (S)

Assuming self as a helping individual understands other people and has the ability to teach

Interest in an environment that encourages individual to be flexible and understand others

Gives high value to social-type activities

Likes to help

Responsible

Cooperative

Idealistic

Social

Patient

Empathy

Wise

Kind

Friendly

Warm

5. Enterprising (E) Interest in managing and influencing other people to achieve personal or organization goal

Assuming self as aggressive, popular, social, confident, motivated, has the ability to speak and lead

Gives high value to economic and political achievement

Likes achievement

Energetic

Likes to travel

Dominant

Optimistic

Easy to agree

Shrewd

Confident

Ambitious

Work hard

Social

Arrogant 
6. Conventional (C)

\author{
Likes structured, systematic and data \\ manipulation activities \\ Assuming self as an individual who \\ conforms to orders, systematic and \\ has the clerical and numbers \\ manipulation skills
}

\author{
Careful \\ Conform \\ Rebellious \\ Defensive \\ Competent \\ Hard headed \\ Dull \\ Decent \\ Structured \\ Not imaginative
}

In conclusion, Holland Theory is based on Holland Hexagonal Model which comprises six personalities, Realistic (R), Investigative (I), Artistic (A), Social (S), Enterprising (E), and Conventional (C). Holland Theory also explains the relationship between personality type with working environment correlation and coefficiently (Holland, 1996).

\section{Social Cognitive Career Theory (SCCT)}

Bandura introduced Self-Efficacy Model, (Bandura, 1986) and Social Cognitive Theory Diagram Model (Bandura, 1986). Self-Efficacy Model explains behavior component, personality factor, and environmental factor that is interdependent, whereas Social Cognitive Theory Diagram Model explains the interaction between choice of career with self-efficacy which finally results in achievement and brings the additional self-efficacy development of an individual (Bandura, 1986).

For Self-Efficacy Model, personality factors such as emotion, self-confidence, and thinking will affect the development of skills and behavior practices influenced by the environment (Lent et al. 1996). Environment and social systems influence human behavior through self-psychology mechanisms (Lent et al, 1996).

Based on Fig. 1.3, expectations from actions and outputs refer to the individual expectation on the output from his actions, while trust and confidence efficacy are mediators of behavior and individual's action (Lent et al. 1996).

For example, output expectation from the action that will be taken by an individual "If I act this way, what will happen?" Further, an example of and self-efficacy towards oneself or self- confidence, "Am I able to act like that?" Therefore, self-efficacy refers to self-trust or confidence stage or degree in an individual before doing an action (Lent et al. 1996).

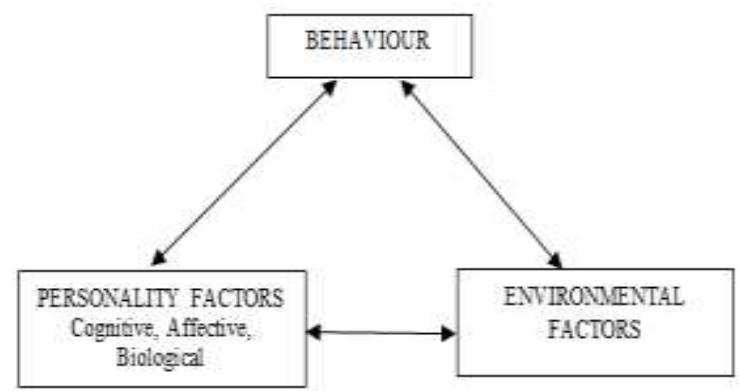

Fig. 1.3. Self-Efficacy Development Component

Further, Fig. 1.4 shows the relationship between confidence efficacy with the expectation of the action from the action taken. It is called the triadic casual system involving three variables, which are self-efficacy, outcome and individual goal (Lent et al. 1996). From the three variables, the most attention given from the literature review was on self-efficacy (Hackett, 1995; Hackett and Lent, 1992; Locke and Latham, 1990).

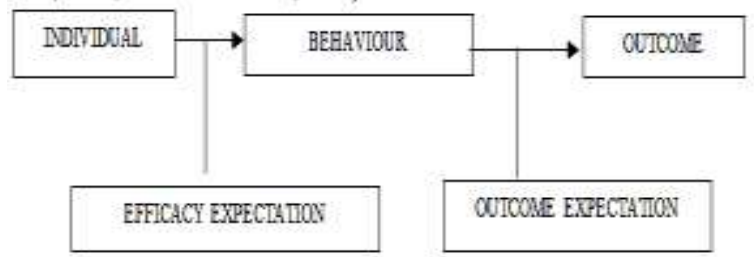

Fig. 1.4. Influence of Self-Efficacy on Behavior

Furthermore, the expected outcome from action means an individual expectation on the outcome of the behavior (Bandura, 1977). Confidence and trust efficacy are the confidence that an individual succeeded in accomplishing an action to create a behavior (Bandura, 1977). However, the expected outcome is different from the confidence and trust efficacy because an individual believes that certain actions will produce an outcome, but if an individual has a high curiosity, whether he can do an activity or not, it will not influence his behavior (Bandura, 1977).

Besides, the expected outcome is individual confidence in effect or outcome in accomplishing a behavior (Lent et al. 1996). Whereas, confidence and trust efficacy is a belief of an individual (Lent et al. 1996). An example of confidence and trust efficacy is "Can I do this?" While an example of an expected outcome is "What will happen if I act this way?" (Lent et al. 1996).

Other than that, an individual also has a particular system that enables him to control his mind, feelings, and actions (Bandura, 1986). In this system, there is one cognitive structure, affective and the abilities to learn, plan alternative strategies, control the behavior abilities and reactions towards self (Bandura, 1986).

Mind functions as the mediator between knowledge and action, make self-considerations, evaluate his experiences and thinking processes (Bandura, 1997). Knowledge, skills, and achievement will be affected and fail if the individuals do not have trust in themselves on their abilities to react (Bandura, 1997).

Furthermore, Social Cognitive Theory Diagram Model is quite complex where it involves interactions between career choice dan self-efficacy, expected outcome, building goals, making choices, outcome and other factors such as academic achievement, gender, race, culture and socioeconomic (Bandura, 1986). 
Fig. 1.5 below shows Social Cognitive Theory Diagram Model by Bandura (1986). Bandura (1986) stated that selfefficacy is formed from the interest which is the main factor when an individual wants to do an activity. When there is an interest, they will form a goal for the activity. If an individual does not interested in the activity, he tends to lose interest in the activity (Scharf, 2010).

Next, an individual's interest will influence his tendency to accomplish an activity and will influence his goal related to the activity (Scharf, 2010). Hence, an individual will do action choices to ensure the formed goal is achieved (Scharf, 2010). Then, an individual will do the chosen action until the target goal is achieved or the expected performance achieved (Scharf, 2010). When an achievement has been produced with excellent performance, it will be considered as a learning experience or as a learning process and will add up to an individual new self-efficacy development (Scharf, 2010). The diagram cycle will continue until the last (Scharf, 2010).

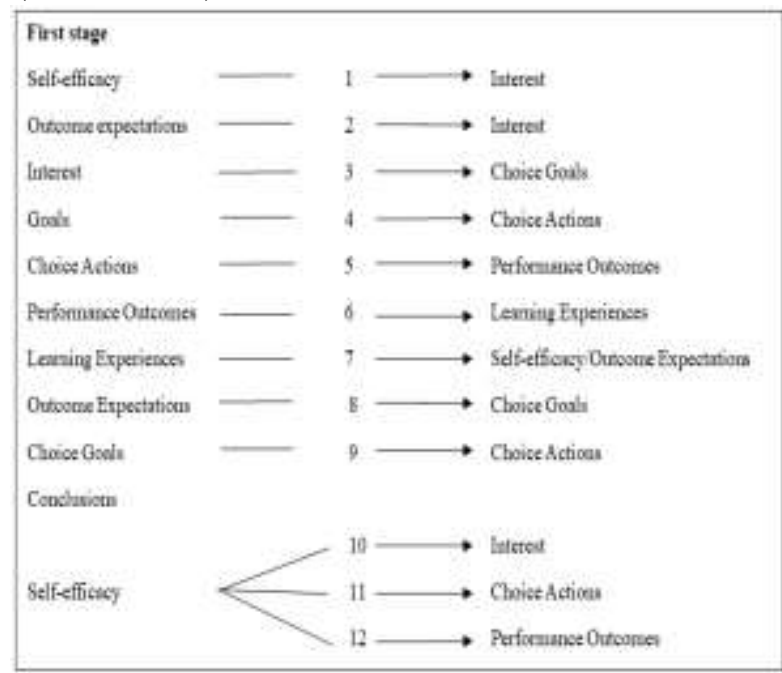

Fig. 1.5. Social Cognitive Theory Diagram Model Source: Sharf (2010)

Next, from the individual development process, Social Cognitive Career Theory explains the Choice Model (Lent et al. 1994). Choice Model describes the individual's background, experience context influence career choice and action choice (Lent et al. 1994). Choice Model can explain individual career action and make career choice as in Fig. 1.6 (Brown and Lent, 1996; Lent et al. 1994; 2000; 2002); in Scharf, 2006). Other than that, Choice Model also explains the nearest context factor to an individual will influence implementation and career achievement that will finally make an individual accomplish the chosen career action (Brown and Lent, 1996; Lent et al. 1994; 2000; 2002); in Scharf, 2006).

Individual factors such as gender, race, ethnic and health status, while individual background factors include socioeconomic status can influence self-efficacy and the expected outcome (Brown and Lent, 1996; Lent et al. 1994; 2000; 2002); in Scharf, 2006). Besides, the individual learning experience can influence self-efficacy formation and the obtainable expected outcome (Brown and Lent (1996); Lent et al. (1994, 2000 and 2002); in Scharf, 2006). Next, career interest formation is obtained through influence from individual factors, background and learning experience that shape two elements, self-efficacy and the expected outcome (Brown and Lent, 1996; Lent et al. 1994; 2000; 2002); in Scharf, 2006).

Meanwhile, after an individual has a career interest, it will motivate him to choose and form the next career interest where the individual will act to think about the

choices of actions or behaviors that can bring to the achievement of his choice of career (Brown and Lent, 1996;

Lent et al. 1994; 2000; 2002); in Scharf, 2006). As the result, an individual will show the best performance and can accomplish his career actions excellently (Brown and Lent,

1996; Lent et al. 1994; 2000; 2002) in Scharf, 2006).

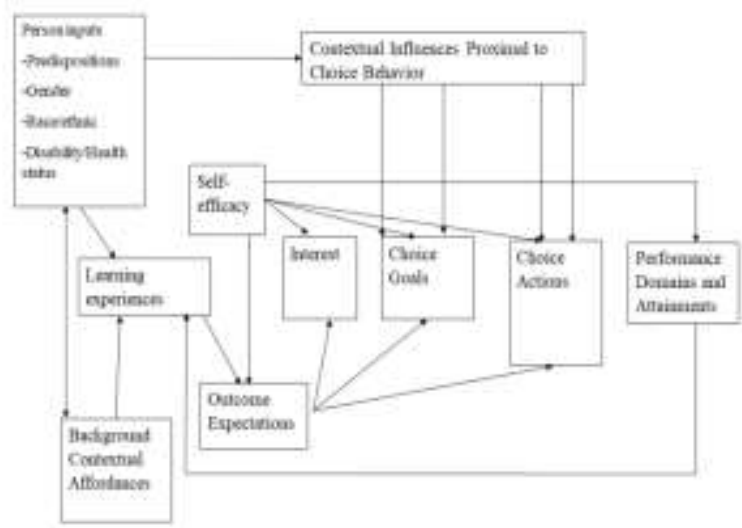

Fig. 1.6. Choice Model

Source from Lent et al. (1994), Scharf (2006; 2010).

\section{E. Career Self-Efficacy}

According to Bandura (1997; 2003), there are four types of self-efficacy:

(a) Self-regulatory self-efficacy - refers to perseverance and an individual's ability to fight, object, endure, fortitude, strength, persistence to challenges and pressure and able to join the high-risk activities.

(b) Social self-efficacy - explains about confidence and individual ability to build and maintain social relationships, has social skills, firmness, cooperate, tolerant, help each other, communicate and connect with a human.

(c) Academic self-efficacy - explains about confidence and an individual's ability to accomplish an academic responsibility, coursework, manage, organize, plan and control academic activities.

(d) Career self-efficacy - relates to an individual's confidence, trust, ability, and capability to consider, choice, making a decision, planning, take action, accomplish tasks, and involve certain careers or jobs.

Therefore, career self-efficacy is one of the self-efficacy types that leads to an individual's confidence, ability to consider career or jobs related to behavior (Fassinger, 2005; Leong and Brown, 1995). If they have high career selfefficacy, they will work hard with perseverance and give the commitment to complete a task. But if they have low selfefficacy, they will not complete the task perfectly.

There are four sources that can influence an individual's self-efficacy level, which is self-experience, vicarious 
learning, verbal encouragement and physiology and psychology (Bandura, 1997 and 2003; Lent et al. 1996; Betz and Hackett, 2006).

i) Self-experience - involves experiences of achievements and failures with the behaviors in the past (Bailey, 2002). If an individual always gets low marks in a certain subject, this will cause him to have low self-efficacy, to continue in the field (Maddux, 1995; Swanson and Woitke, 1997). However, if a student excels in completing a technical task in an engineering subject, he will have high self-efficacy in the engineering field (Speight, Rosenthal and Gasteenval, 1995).

ii) Vicarious learning - experiences from other people. Betz and Hackett (2006) stated that students who can see and share from a successful model will have a tendency to influence the same ability and success as the model. According to Brown (1999, 2003), if by observing the behavior of other people who they choose to be a model, the observer believes that they have the ability to do the same thing as the model did.

According to Komarraju et al. (2014), activities that can be done through vicarious learning are an interview with professionals in the field, learn about a career path, and the method of being a successful person at work, industrial training and attending workshops or programs related to career.

iii) Verbal Support and Encouragement - involves support (or no support) to other people through communication-related to behavior. According to Ormrod (1998), if an individual is encouraged, he is able to complete a task successfully, and this will increase his career selfefficacy.

iv) Physiological and psychological - involves the human body in a pressure situation, anxiety, fatigue, scared, pain, curious, muscle strain, stress, nausea, and sweating with panic can significantly affect the self-efficacy level. Pain and scared effect will implicate cognitive, psychology, affective and emotion performance in an individual (Bandura, 1997). According to Bandura, the state that contributes to physiological uncertainty is caused by connections with the individual's environment and emotional reactions or things that touch his feelings.

These main factors will effect the formation of selfefficacy from the confidence degree whether is low or high level and then the formation of the individual behavior act or action (Mohd Sani Ismail, 2011).

In conclusion, Social Cognitive Career Theory was originally introduced by Bandura in 1986 with the name Social Cognitive Theory and then expanded to Social Cognitive Career Theory by Lent et al. in 1996. Social Cognitive Career Theory explains goals, self-efficacy and expected outcomes that influence one another in selfregulatory of behavior (Lent et al. 1996).

Next, Social Cognitive Career Theory also explains in detail about career development that can help an individual to achieve career goals (Scharf, 2010). These are a few justifications of choosing Social Cognitive Career Theory as a Career Theory to explain Career Self-Efficacy.

\section{F. Justification of Choosing Social Cognitive Career} Theory as Career Theory to Explain Career Self-Efficacy

According to literature reviews, there are a few career theories that are commonly used by most of the previous researchers to explain on individual career aspect. Among the theories are Social Cognitive Career Theory (Bandura, 1977; Lent et al. 1996), Life Span Theory (Super, 1957), and Holland's Theory (Holland, 1959). However, in this study, the researcher has chosen Social Cognitive Career Theory which was introduced by (Bandura, 1977; Lent et al. 1996) as the study's theoretical based to explain career selfefficacy based on a few justifications.

Life Span Theory (1957) is seen as inappropriate to be the theoretical based in this study to explain career self-efficacy variables due to some limitations. For instance, Life Span Theory is seen to emphasis more on self-concept, career maturity and the career value itself (Bandura, 1977), whereas the main aspect studied was career self-efficacy which refers to the level of ability, talent, skills, trust and confidence of an individual towards himself in making consideration to choose his career (Hackett and Betz, 1981; Betz and Hackett, 1986).

Other than that, Life Span Theory (1957) is also incomprehensive making it hard to study overall (Capuzzi and Stauffer, 2005). This actually means that there are parts of the theory that can be explained on themselves and studied separately from other aspects (Capuzzi and Stauffer, 2005). Besides, Super's Career Theory (1957) also explains that men are not suitable to work as clerks, administrative assistants, and office boys when these careers still choose by men. This means that there is a job classification based on gender and this is seen as outdated and not moved with the times.

Next, Holland's Career Choice Theory was not chosen to be the theoretical based in this study because of some limitations. This is because Holland's Career Choice Theory is suitable to explain the relationship between personality types and environment (Holland 1973, 1978 and 1985) where it looks at the congruency between personality types and working environment to influence the job satisfaction and achievement. However, career self-efficacy is one of the most important aspects that should be emphasized for career determination and life path (Ahmad Esa and Azmi Hassan, 2013). Therefore, this study will focus on career selfefficacy that relates to an individual's ability, talent, skill, trust and confidence toward himself in making consideration of his career (Hackett and Betz, 1981; Betz and Hackett, 1986). Holland's Theory also does not emphasis on behavior change process in individual interaction with his environment where the study on the interaction of individual and his working environment is not done analytically and comprehensive (Holland, 1974).

Therefore, Holland suggested that future research emphasis on a behavior change process that covers increasing satisfaction in making career decisions (Holland, 1974).

Besides, Holland's Career Choice Theory also criticized 
for being bias in measuring race and gender (Anderson, Tracey and Rounds 1997; Haverkamp, Collins, and Hansen, 1994) and also Hexagonal Model is seen bias in gender and culture (Hansen et al. 1993; Tinsley, 2000). Furthermore, Holland's Career Choice Theory has also been criticized for not emphasizing the culture role in maintaining the working environment (Capuzzi and Stauffer, 2005).

Based on the explanation, the researcher chose the Social Cognitive Career Theory as theoretically based on this study to describe the career self-efficacy variable based on the justifications. Social Cognitive Career Theory has been used by most of the previous researchers who study career intervention on career self-efficacy (Mohd Izwan Mahmud, 2017; Chiesa et al. 2016; Joslyn, 2015; Jasmi, 2014; Komarraju et al. 2014; Smothers, 2012; McWhirter et al. 2000). Other than that, talent impact on self-efficacy and influence on expected outcomes and interest also emphasized in this theory (Lopez et al. 1997).

Besides, some studies that use Social Career Cognitive Theory framework also show that career self-efficacy plays an important role in planning and development of an individual's career (Gushue and Whitson, 2006; Lease, 2006; Lent et al. 2001; Lent et al. 2003; Lent et al. 2005). Other than that, Social Career Cognitive Theory also emphasis on self-efficacy aspect in choosing a career internally and externally (Scharf, 2010; Gushue and Silvia, 2003).

Further, Social Cognitive Career Theory also emphasis on expected outcome and goal building aspects as variables in academic and career choice (Scharf, 2010; Joslyn, 2015). Goal building is a determinant of the settlement of a task or working hard to achieve target outcome (Bandura, 1986) which is a drive for an individual to achieve his target or ambition in education and career (Lent, 2013).

Next, most of the researchers use Social Cognitive Career Theory as a based theory for self-efficacy variable dan use it to expand the latest Bandura's theory to better understand career behavior (Lent, 2005; Lent et al. 1994, 2000).

\section{CONCLUSION}

Based on the extensive elaboration above, it is clear that SCCT (Bandura, 1986; Lent et al. 1996) is a most suitable career theory to explain CSE. After the comparison made between other career theories, it is found that CSE clearly explains in detail about CSE because of the justifications mentioned. Therefore, SCCT is chosen based on the compatibility and advantages it has compared to other career theories.

\section{REFERENCES}

1. Ahmad Esa \& Azmi Hassan. (2013). Saya yakin saya boleh! Dalam Buku Menggapai Bintang. Skudai: Penerbit UTM.

2. Anderson, M.Z., Tracey, T.J.G., \& Rounds, J. (1997). Examining the invariance of Holland's vocational interest model across gender. Journal of Vocational Behaviour, 50, 349-364.

3. Bailey C.J. (2002). Applying the five-factor model of personality to undergraduate career attitudes and beliefs: maturity, decision-making self-efficacy, and control. Tesis Ph.D. University of Missouri, Kansas City. Whitson, 2006; Lent et al. 1994, 1996; Lent et al. 2008; and

4. Bandura, A. (1977). Social learning theory. Englewood Cliffs, NJ: Prentice-Hall, Inc.

5. Bandura, A. (1986). Social foundations of thought and action: A social cognitive theory. Englewood Cliffs, NJ: Prentice-Hall, Inc.

6. Bandura, A. (2000). Social cognitive theory: An agentic perspective. Annual Review of Psychology, 52, 1-26.

7. Bandura, A. (2003). Self -efficacy: the exercise of control. Ed. ke-7. New York: Freeman and Company.

8. Bandura, A. (2006). Toward a psychology of human agency. Perspectives on Psychological Science, 1(2), 164-180.

9. Bandura, A. (2007). Much ado over a faulty conception of perceived self-efficacy grounded in faulty experimentation. Journal of social \& clinical psychology, 26(6), 641-658.

10. Bandura, A. (1997). Self-efficacy: The exercise of control. New York: Freeman and Company.

11. Betz N., \& Hackett G. (2006). Career self-efficacy theory: back to the future. Journal of Career Assessment, Vol. 14, No. 1, February 2006, 3-11.

12. Betz, N. E. \& Hackett, G. (1986). Applications of SelfEfficacy Theory to Understanding Career Choice Behavior. Journal of Social and Clinical Psychology, 4(3), 279-289.

13. Brown, D. (1999). Improving Academic Achievement: What School Counselors Can Do. ERIC ED435895.

14. Brown, D. (2003). Career information, career counseling, and career development. New York: Allyn and Bacon.

15. Brown, D., Brooks, L., \& Associates. (1996). Career choice and development (3rd ed.). San Francisco: JosseyBass.

16. Brown, S.D. \& Lent, R.W. (1996). A social cognitive framework for career choice counseling. The Career Development Quarterly.44:355-377.

17. Capuzzi D. \& Stauffer M.D. (2005). Career Counseling Foundations, Perspectives, and Applications. Oregon State University, Pearson Education Inc.

18. Chiesa, R., Massei, F. \& Guglielmi, D. (2016). Career decision-making self-efficacy change in Italian high school students. Journal of Counseling \& Development, 94, 210-224.

19. Fassinger, R. E. (2005). Theoretical issues in the study of women's career development: Building bridges in a brave new world. In W. B. Walsh \& M. L. Savickas (Eds.), Handbook of vocational psychology (3rd ed., pp. 85-126). Mahwah, NJ: Lawrence Erlbaum Associates

20. Fouad, N., Cotter, E. W., \& Kantamneni, N. (2009). The effectiveness of a career decision-making course. Journal of Career Assessment, 17, 338-347.

21. Gianakos, I. (2001). Predictors of career-decision making self-efficacy. Journal of Career Assessment, 9, 101-114.

22. Gushue, G. V, Clarke, C. P., Pantzer, K. M., \& Scanlan, K. R. L. (2006). Self-Efficacy, Perceptions of Barriers, Vocational Identity, and the Career Exploration Behavior of Latino /High School Students. Career Development Quarterly, 54(June), 307-317.

23. Gushue, G. V. dan Whitson, M.L. (2006). The relationship of ethnic identity, career decision-making self-efficacy and outcome expectations in African AMerican High school students. Journal of Vocational Behavior, 33 (2), 112-124

24. Hackett, G. (1995). Self-efficacy in career choice and development. In A.Bandura (Ed.), Self-efficacy in changing societies (pp. 232-258). Cambridge, U.K: Cambridge University Press.

25. Hackett, G. \& Betz, N. E. (1981). A self-efficacy 
approach to the career development of women. Journal of Vocational Behavior. 18(3), 326-339.

26. Hackett, G., \& Lent, R. W. (1992). Theoretical advances and current inquiry in counseling psychology. In Handbook of counseling psychology (2nd ed., pp. 419 462). New York: Wiley.I

27. Hansen, J.I.C., Collins, R.C., Swanson, J.L., \& Fouad, N.A. (1993). Gender differences in the structure of interests. Journal of Vocational Behaviour, 42, 200-211.

28. Haverkamp, B.E., Collins, R.C., \& Hansen, J.I. (1994). Structure of interest of Asian-American college students. Journal of Counseling Psychology, 41, 256-264.

29. Holland, J.L. (1973). Making a vocational choice: a theory of careers. Englewood Cliff, New Jersey: Prentice Hall Inc.

30. Holland, J.L. (1974). Self-Directed Search. Palo Alto. CA: Consulting Psychologist Press.

31. Holland, J.L. (1978). Manual for the vocational preference inventory. Palo Alto, California: Consulting Psychologist Press.

32. Holland, J.L. (1985). Manual for the vocational preference inventory. Odessa, FL: Psychological Assessment Resources.

33. Holland, J.L. (1992). Making vocational choices: a theory of vocational personalities and work environments (2nd ed.). Odessa Florida: Psychological Assessment Resources.

34. Holland, J.L. (1996). Making vocational choices: a theory of vocational personalities and work environments. Odessa Florida: Psychological Assessment Resources.

35. Isaacson, L.E. \& Brown, D. (2000). Career Information, Career Counseling \& Career Development. (7th, ed.) Boston: Allyn and Bacon.

36. Jasmi Abu Talib.(2014). "Kesan modul kembara kerjaya ke atas kebolehan merancang kerjaya, efikasi kendiri membuat keputusan kerjaya dan kematangan kerjaya pelajar kolej komuniti." Tesis $\mathrm{PhD}$, Universiti Kebangsaan Malaysia, Bangi.

37. Jin, L., Watkins, D., \& Yuen, M. (2009). Personality, career decision self-efficacy, and commitment to the career choices process among Chinese graduate students. Journal of Vocational Behavior, 74, 47-52.

38. Joslyn, Brittany Melvin, F. S. U. (2015). Exploring the impact of a career development intervention on the career decision-making self-efficacy and goal instability of firstgeneration college students, given perceived barriers. Tesis Ph.D., Florida State University, United States.

39. Komarraju, M., Swanson, J. \& Nadler, D. (2014). Increased Career Self-Efficacy Predicts College Students' Motivation, and Course and Major Satisfaction. Journal of Career Assesment. 22(3), 420-432.

40. Lease, S. H. (2006). Factors predictive of the range of occupations considered by African American juniors and seniors in high school. Journal of Career Development, 32, 333-350.

41. Lent, R. (2013). Social cognitive career theory. In S. D. Brown \& R. W. Lent (Eds.), Career development and counseling: Putting theory and research to work. (2nd ed., pp. 115- 146). Hoboken, NJ: John Wiley \& Sons, Inc.

42. Lent, R. W., Brown, S. D., \& Hackett, G. (1996). Career Brown \& L. Brooks (Eds.), Career choice and development (pp. 373-421). San Francisco, CA: JosseyBass

43. Lent, R. W., Brown, S. D., Brenner, B., Chopra, S. B., Davis, T., Talleyrand, R., \& Suthakara, V. (2001). The role of contextual supports and barriers in the choice of math/science education options. Journal of Counseling Psychology, 48, 474-483. development from a social cognitive perspective. In D.

44. Lent, R. W., Brown, S. D., Schmidt, J., Brenner, B., Lyons, H., \& Treistman, D. (2003). Relation of the contextual supports and barriers to choice behavior in engineering majors: Test of the alternative social cognitive model. Journal of Counseling Psychology, 50, $458-465$.

45. Lent, R. W., Brown, S. D., Sheu, H., Schmidt, J., Brenner, B. R., Gloster, C. S., \& Treistman, D. (2005). Social cognitive predictors of academic interests and goals in engineering: Utility for women and students at historically Black universities. Journal of Counseling Psychology, 52, 84-92.

46. Lent, R. W., Sheu, H., Singley, D., Schmidt, J. A., Schmidt, L. C., \& Gloster, C. S., (2008). Longitudinal relations of self-efficacy to outcome expectations, interests, and major choice goals in engineering students. Journal of Vocational Behavior, 73, 328-335.

47. Lent, R.W., Brown, S.D., \& Hackett, G. (1994). Toward a unifying social cognitive theory of career and academic interest, choice and performance. Journal of Vocational Behaviour, 45, 79-122.

48. Lent, R.W., Brown, S.D., \& Hackett, G. (2000). Contextual supports and barriers to career choice: a social cognitive analysis. Journal of counseling psychology, 47, 36-49.

49. Lent, R.W., Brown, S.D., \& Hackett, G. (2002). Career development from a social cognitive perspective. In D. Brown, L. Brooks, and Associates, Career choice and development, (Edisi Keempat), 255-311. San Francisco: Jossey-Bass.

50. Leong, F. T. L., \& Brown, M. T. (1995). Theoretical issues in cross-cultural career development: Cultural validity and cultural specificity. In W. B. Walsh, \& S. H. Osipow (Eds.), Handbook of vocational psychology: Theory, research, and practice (2nd ed., pp. 143-180). Mahwah, NJ: Lawrence Erlbaum Associates.

51. Locke, E.A., \& Latham, G.P. (1990). A theory of goal setting and task performance. Eaglewood Cliffs, NJ: Prentice Hall.

52. Lopez, F. G., Lent, R. W., Brown, S. D., \& Gore, P. A., Jr. (1997). Role of social-cognitive expectations in high school students' mathematics related interest and performance. Journal of Counseling Psychology, 44, 4452 .

53. Maddux, J. E. (1995). Self-efficacy theory: An introduction. Dalam Self efficacy, adaption, and adjustment: Theory, research, and application (pp.3-33). New York, NY: Plenum Press.

54. McWhirter, E.M. Rasheed, S. \& Crothers, M. (2000). The effects of a high school career education on socialcognitive variables. Journal of Counseling Psychology, 47(3), 330-341.

55. Mohd Izwan Mahmud, Sidek Mohd Noah, Jamaludin Ahmad \& Wan Marzuki Wan Ahmad. (2016). Modul Kesediaan Kerjaya Berdasarkan Teori Cognitive Information Processing (CIP). Jurnal Kurikulum \& Pengajaran Asia Pasifik, 4(3), 59-75.

56. Mohd Izwan Mahmud. (2017). Kesan program kerjaya psiko-pendidikan cognitive. information processing terhadap ketidakfungsian pemikiran kerjaya dan efikasi kendiri kerjaya pelajar di sebuah universiti awam. Tesis PhD: Universiti Putra Malaysia, Serdang.

57. Mohd Sani Ismail. (2011). Kematangan kerjaya, efikasi kendiri kerjaya, dan penglibatan pelajar dalam aktiviti program bimbingan dan kaunseling kerjaya. Tesis Doktor Falsafah yang tidak diterbitkan. Universiti Kebangsaan Malaysia, Bangi, Selangor. 
58. Nauta, M.M. (2004). Self-efficacy as a mediator of the relationship between personality factors and career interests. Journal of Career Assessment, 12, 381-394.

59. Ormrod, J.E. (1998). Educational psychology: Development learners. New York Prentice-Hall.

60. Patton W. (1999). Career development and systems theory: a new relationship. The Queensland University of Technology. Brooks/Cole Publishing Company.

61. Reese, R.J., \& Miller, C. (2006). Effects of a university career development course on career decision-making self-efficacy. Journal of career assessment, 14, 252-266.

62. Review of Business. 21:38-42

63. Rogers, M. E., Creed, P. A., \& Glendon, A. I. (2008). The role of personality in adolescent career planning and exploration: A social cognitive perspective, Journal of Vocational Behavior, 73, 132-142.

64. Savickas, M.L. (1997). Career adaptability: an integrative construct for life-span, life-space theory. The career development quarterly, March 1997, Vol. 45, 247-259.

65. Scharf R. (2006). Applying career development theory to counseling. (5th Edition). Pacific Grove, CA: Brooks/Cole.

66. Scharf R. (2010). Applying career development theory to counseling. (5th Edition). Pacific Grove, CA Brooks/Cole.

67. Silvia, P. J. (2003). Self-efficacy and interest: Experimental studies of optimal incompetence. Journal of Vocational Behavior, 62, 237-249.

68. Smothers, A. W. (2012). Career cruising impact of deciding majors. Tesis Ph.D., University of Northern Iowa.

69. Speight, J.D., Rosenthal, K.S. \& Gastenveld, B.J. (1995) Medcamp's effect on junior high school students' medical career self-efficacy. The Career Development Quarterly, 43(3): 285-291.

70. Super, D.E. (1957). The psychology of careers. New York: Harper \& Row.

71. Super, D.E. (1971). The psychology of career. New York: Harper \& Row Publisher.

72. Swanson, J., \& Woitke, M. (1997). Theory into practice in career assessment for women: Assessment and interventions regarding perceived career barriers. Journal of Career Assessment, 5, 443-462.

73. Tinsley, H.F.A. (2000). The congruence myth: an analysis of the efficacy of the person-environment fit model. Journal of Vocational Behaviour, 56, 147-179.

74. Wang, N., Jome, L. M., Haase, R. F., \& Bruch, M. A. (2006). The role of personality and career decisionmaking self-efficacy in the career choice commitment of college students. Journal of Career Assessment, 14, 312332 .

75. Zalizan Mohd Jelas, Amla Mohd Salleh, Norzaini Azman, Ramlah Hamzah, Rohana Jani, Hanizah Hamzah, Zaleha Abd Hamid dan Mohd Izwan Mahmud. (2013). Laporan penyelidikan: Analisis gender dalam Pendidikan. Kementerian Pendidikan Malaysia.

\section{AUTHORS PROFILE}

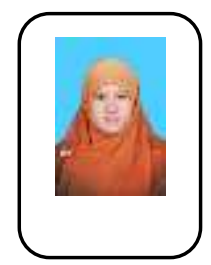

Nik Rafidah is presently a $\mathrm{PhD}$ candidate in the Universiti Teknologi Malaysia (UTM). She has completed her Master and Bachelor Degree in Guidance and Counseling in education, Universiti Teknologi Malaysia. She actively involved in career counseling activities and programs at Universiti Teknologi Malaysia.

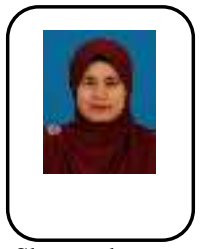

Dr Mastura Mahfar is a senior lecturer in counselling in the School of Human Resource Development and Psychology at Universiti Teknologi Malaysia. She holds a PhD in Guidance and Counselling from Universiti Putra Malaysia. Her research interest includes stress intervention and workplace counselling. She teaches counselling and psychology courses and supervises master and doctoral projects within these fields.

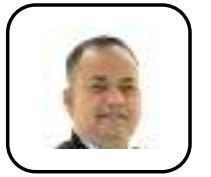

Professor Dr Muhammad Sukri Saud is currently working in the Department of Technical and Engineering, School of Education, Faculty of Human Sciences and Humanities, Universiti Teknologi Malaysia. He completed his $\mathrm{PhD}$ in Human Resource and Community Development from the Ohio State university, USA. He is actively involved in research on career and talent development of students and the community. He has given numerous presentations, organized meeting, performed research and authored numerous peer-reviewed articles in Career and Technical education (CTE). He is actively involved in supervising $\mathrm{PhD}$ and Master students. 